\title{
PORTUGAL, THE MEDITERRANEAN AND THE ATLANTIC. GEOGRAPHICAL STUDY
}

\author{
RUI F. CARVALHO ${ }^{1}$
}

Portugal, o Mediterrâneo e o Atlântico [Portugal, the Mediterranean and the Atlantic]:2 Regardless of their branches of study, areas of expertise, or even epistemological views of the geographical praxis and theorization, very few Portuguese geographers would not claim knowledge of, and reverence for, this seminal piece and, more generally, of its author's work. Un-arguably one of (if not) the most distinguished and recognised Portuguese Geography professors and researchers, and one of the most important European geographers of the $\mathrm{XX}^{\text {th }}$ century, Orlando Ribeiro (1911-1997) numbered among his many career achievements the creation of the renowned Centre for Geographical Studies of the University of Lisbon and the organization of the first post-war congress of the International Geographical Union (1949), a group for which he was elected vice-president in 1952. As stated in the website dedicated to the spreading of his life and work $\mathrm{i}$, "particularly important landmarks [hence definitely not falling short from those mentioned earlier] of his career are Portugal, o Mediterrâneo e o Atlântico, one of his best known works of synthesis, first published in 1945, and the creation of Finisterra in 1966, a journal that still continues as one of the major publications to divulge the Portuguese geography, at a national and international level."

Given the previously stated, the intended purpose of this text is - through the association of these two landmarks, and taking the opportunity for dissemination provided by an issue of Finisterra published in English - to contribute to expand on the festivities of the centenary of his birth, which took place all around the year 2011, through the presentation and reviewing of the latest (the $8^{\text {th }}$ ) ii and celebratory edition of Portugal, o Mediterrâneo e o Atlântico, published in that same year.

The Portugal presented in this book through the hand of this regionalist and humanistic geographer is a markedly rural one; one with a predominantly agrarian economy; one deeply marked by history, and physiographic and climatic features; one resulting from the combination of a myriad of Mediterranean and Atlantic influences whose human expressions were still widely visible at the time of its original writing (1945). Synthetically, the author expands

1 Research assistant at the Centre for Geographical Studies of the Institute of Geography and Spatial Planning, University of Lisbon. E-mail: racarvalho@fl.ul.pt.

2 Ribeiro O (2011) Portugal, o Mediterrâneo e o Atlântico. Estudo Geográfico. Lisbon: Letra Livre, 8th ed. (1st ed. [1945]), 232 pp. [ISBN: 978-9898268105]. [Title in English: Portugal, the Mediterranean and the Atlantic. Geographical Study]. 
the classical notion advanced by Pequito Rebelo (1929) by which he considered that Portugal is "Mediterranean by nature and Atlantic by its geographical situation" (p. 63) ${ }^{\mathrm{iii}}$. Following this line of reasoning, O. Ribeiro thoroughly describes and compares an "Atlantic North(west)" - moist, lively and fertile; of intense oceanic influence; an everlasting breeder of a dense population, whose historical relevance in the peopling of the country and even of its (former) colonies was, as constantly referred to in the book, of the utmost importance - to a greyish and harsher "Interior North(east)", a region branded by extremes, where the "land is harder and the peoples are rougher". To these two regions he contrasts a "Mediterranean South", one in which the vast and dry plains of Alentejo end up masking (at least for those less knowledgeable or attentive) an immense heterogeneity patented, for example, by the complex reliefs and climatic characteristics of the surroundings of Lisbon and Setubal or by the coexistence of the "two distinct Algarves" (p. 195-197). Between and within these larger regions, local combinations of the simultaneous influences of latitude, altitude and proximity to the coastline, imprint idiosyncratic profiles to each area leading to vernacular landscapes and forms of human appropriation of space and nature which have cumulatively evolved or, in many situations, remained almost untouched, throughout the centuries.

It is the outcomes of, and also the explanations for, these complex influences that are presented by O. Ribeiro - in more than 200 pages, including some (extremely) informative maps, to be found at the end of the book -, in an eloquent and passionate way, and displaying an immense knowledge, as well as a penetrating concern, for both "the land and the people". In this regard, the book Portugal, o Mediterrâneo e o Atlântico was, and - in spite of some anachronisms and the out-dated character of certain explanations and interpretations, to be expected in a work with more than six decades of existence - remains a notable piece of research and tutorship on the physical and human geography of Portugal, on its history and populations, and even on the roots of national and regional identity, for example, through the unequivocal refusal of the geographical homogeneity of Portugal and the clear dismissal of (ethnically) deterministic and excessively credulous explanations for the country's individuality and nationhood, recurrent at the time it was written.

Being this a special thematic issue dedicated to the field of Migration Studies, it would be of interest to lay some attention on fragments in the referenced work that relate to such a scope of study. A merely superficial analysis would get one to the conclusion that the description of population movements is not generally the main focus of the author. Furthermore, when these topics are approached it is normally in reference to low-scale local (rural) dissemination movements or to seasonal internal migrations (either temporary or definitive) stimulated by the prevailing agricultural economy of the country. Although this latter characteristic may be posited as a strong reason for a greater consideration for these mainly ruralized movements, it is not to be disregarded that, in the early 1940's, the country was already facing - even if not at the same scale and intensity as in other European countries - a process of urbanization, with the city of Lisbon, for example, already displaying almost 700000 residents in 1940. Even though this phenomenon is at times mentioned in the work, a deeper insight on prevailing tendencies for urban concentration (and on cities and urban areas in general) would have been a positive addition to the book, even if one not of mandatory importance for its intended purpose.

Additionally, emigration is also addressed in some sections of the book. Economic (p. 42), ecological (p. 56-57) and historical (p. 136-137) factors are mentioned as causes for out-ward migratory movements of the Portuguese population. O. Ribeiro also acknowledges the existence of a "migratory calling" in the population of some regions, particularly visible 
in the over-populated Northwest (p. 136-137) and also in the Algarve (p. 207), a characteristic manifested generally by the inhabitants of the whole Mediterranean Basin, where "the land is poor and populations are numbered" (p. 56-57).

Conversely, immigration is - naturally, given the time of writing - virtually absent from the book. However, a deeper analysis of the work, one that is melted with some understanding of Portugal's recent migratory background, exposes several (very) interesting fragments of information that, more or less directly, relate and may even contribute to explain certain facets of what contemporary Portugal is in terms of immigration.

In a recent (2012) fieldwork experience interviewing Moroccan immigrants living in the Algarve $\mathrm{i}^{\mathrm{iv}}$, the intense acquaintance of $\mathrm{O}$. Ribeiro with the Portuguese and the Mediterranean land(s) and people(s) became clear. Moreover, the up-to-date character of such knowledge proved to be remarkable. Statements like "the toughness of the work, the parsimony of their eating habits, the simplicity of their ways of living, are elements that allow Mediterraneans to easily adapt to every context" (p. 41-42), or "to the physical unity may be imputed the easiness with which Mediterraneans have moved from one place to another [in the Mediterranean] without substantially altering their ways" (p. 54) have proved their validity and diachronism throughout the aforementioned fieldwork. Additionally, words like "[wherever he goes] the native from the Algarve carries with him his adaptability, his open and comforting look, his taste for laughing and talking; with his well-known liveliness he is, both in terms of his geographical situation and in his ways, the most southerly of all the Portuguese" (p. 207) found, more than 60 years after they were first written, a contemporary match in expressions by Moroccan interviewees living in the Algarve: "[Portugal is] an amazing country and the people are really kind" (Male, 39 years)"; "people in Morocco often ask me about Portugal, how the Portuguese are (...) and I say that everything is the same as in Morocco; what Morocco has, Portugal has in the same way" (Female, 29 years); "if you compare Portugal and Morocco you will have the same weather, the same mentality; the only difference between the two is religion" (Male, 36 years); or "actually, Portuguese people are very welcome in Morocco. (...) it seems to me that the Portuguese and the Moroccan feel naturally acquainted amongst each other" (Male, 39 years). In a similar vein, words like "to a British person, a German one or even to those from Northern France, these [Mediterranean] places are already encased with an exoticism that preludes that of Moorish Africa or the Far East" (p. 61) appear to have been written with a prescient disposition on lastdecades' ascent of many Mediterranean regions (including, for example, the Alentejo or the Algarve) as areas of destination for large numbers of international retirement migrants from those countries ${ }^{\mathrm{vi}}$.

This is a book about what almost appears to be "another country". Portugal is no longer markedly rural; nor does an agrarian economy prevail nowadays. The book is also a landmark of what almost seems to be "another Geography"; one that is (too) passionate about "the land and the people"; one many would consider as outlying contemporary scientific concerns and methods. Yet, perhaps the most important idea the book has to offer is the acknowledgement of the importance of understanding the past to systematically know the present. After reading it, no matter how anachronic it may appear at times, and just by knowing more about that "obsolete country" and that "old-fashioned Geography" one cannot help to admit a deeper knowledge of the contemporary ones; it even gets one wondering if one ever knew them at all. 
i www.orlando-ribeiro.info/home.htm.

ii The last available edition (the $7^{\text {th }}$ ) dated from 1998; also worthy of notice is the 1993 reprint of the work which included photographic illustrations by the photographer Jorge Barros.

iii All quotations presented here were translated from the original book in Portuguese.

iv Fieldwork conducted in the context of the international project THEMIS coordinated nationally by Professor Lucinda Fonseca at the Centre for Geographical Studies of the University of Lisbon and, internationally, by the International Migration Institute of the University of Oxford. For further information on the project consult: http://www.imi.ox.ac.uk/research-projects/themis.

$v$ All quotations from the interviews presented here were translated from the original transcripts in Portuguese.

vi For further evidence on this topic see a dissertation recently written by a research assistant at the Centre for Geographical Studies of the University of Lisbon: Sampaio, D (2011) Migrações pósreforma em áreas de baixa densidade do Algarve: um olhar da geografia na perspectiva do desenvolvimento local. MA thesis, University of Lisbon, Lisbon. [Title in English: Retirement migration in lowdensity areas of the Algarve: A geographical gaze from the perspective of local development] 